\title{
EFFECTS OF EXERCISE TYPE AND INTENSITY ON VISFATIN AND THE METABOLIC SYNDROME IN OBESITY
}

Original Article ARTIGO ORIGINAL

EFEITOS DO TIPO DE EXERCÍCIO EDA INTENSIDADE NA VISFATINA E A SÍNDROME METABÓLICA Artículo Original

\author{
NA OBESIDADE
}

EFECTOS DEL TIPO DE EJERCICIO Y DE LA INTENSIDAD EN LA VISFATINA Y EL SÍNDROMEMETABÓLICO

EN LAOBESIDAD

Jang-kyu Lee1 (D)

(Physiologist)

1. Dankook University, College of Sports Science, Department of Exercise Prescription and Rehabilitation, Cheonan-si, Republic of Korea.

\section{Correspondence:}

Jang-Kyu Lee

Assistant Professor. Dankook

University, College of Sports

Science, Department of Exercise Prescription and Rehabilitation. 119 Dandae-ro, Dongnam-gu, Cheonan-si,

Chungchenongnam-do, Korea. kyu1216@hanmail.net.

\begin{abstract}
Objective: Visfatin may regulate a variety of physiological functions and it has great potential to significantly enhance our knowledge of the treatment of metabolic syndrome. Metabolic syndrome (MS) refers to metabolic abnormalities, such as abdominal obesity, dyslipidemia, high low-density cholesterol, high blood pressure and diabetes, and physical activity is an important factor for the management of MS. Therefore, the purpose of this study is to investigate the effects of visfatin on MS and MS risk factors through differences in aerobic exercise intensity and exercise type based on the premise of the same amount of exercise (energy expenditure of $400 \mathrm{kcal}$ per day). Method: Thirty two obese, middle-aged women were randomly assigned to exercise intensity groups $\mathrm{VO}_{2}$ max $50 \%(\mathrm{MAE}, \mathrm{n}=8)$ and $\mathrm{VO}_{2}$ max $80 \%(\mathrm{VAE}, \mathrm{n}=8)$ and to type of exercise groups $\mathrm{VO}_{2} \max 50 \%+$ TRX (MARE, $\mathrm{n}=8$ ) and $\mathrm{VO}_{2} \max 80 \%+$ TRX (VARE, $\mathrm{n}=8$ ). The exercise program was performed 5 times a week. The data was analyzed using two-way repeated measures ANOVA and post-hoc tests within groups with LSD. Results: Body weight ( $p<.01$ and $p<.001)$ and $\%$ body fat $(p<.05$ and $p<.01)$ significantly decreased in all groups and visfatin only increased significantly after exercise in the VARE group ( $p<.05)$. TG, glucose, and waist circumstance $(p<.05, p<.01$, and $p<.001)$ significantly decreased in all groups and HDL-C $(p<.05)$ only increased significantly after exercise only in the MARE group. Conclusion: These results suggest that, in spite of differences in exercise intensity and exercise type, exercise is effective in improving obesity and MS risk factors, but further research is needed on the exact mechanisms of visfatin. Level of evidence l; Therapeutic Studies Investigating the Results of Treatment.
\end{abstract}

Keywords: Visfatin; Metabolic syndrome; Exercise type; Exercise mode.

\section{RESUMO}

Objetivo: A visfatina pode regular diversas funções fisiológicas e tem grande potencial para aprimorar significativamente nosso conhecimento sobre o tratamento da síndrome metabólica. A síndrome metabólica (SM) refere-se a anormalidades metabólicas, como obesidade abdominal, dislipidemia, colesterol de baixa densidade elevado, hipertensão e diabetes, sendo a atividade fisica um fator importante para o manejo da SM. Assim sendo, o objetivo deste estudo é investigar os efeitos da visfatina sobre os fatores de risco de SM por meio de diferenças da intensidade de exercícios aeróbicos e do tipo de exercício, com base na premissa de mesma quantidade de exercício (gasto energético de 400 kcal por dia). Método: Trinta e duas mulheres obesas de meia-idade foram randomicamente designadas para grupos de intensidade de exercício com VO ${ }_{2 \text { máx }}$ de $50 \%$ (EAM, $\left.n=8\right)$ e VO $\mathrm{V}_{\text {máx }}$ de $80 \%(E A V, n=8)$ e grupos com $V_{2 m a ́ x}$ de $50 \%$ $+E R C(E A R M, n=8)$ e $V O_{2 m a ́ x}$ de $80 \%+E R C(E A R V, n=8)$. O programa de exercícios foi realizado 5 vezes por semana. Os dados foram analisados com ANOVA de duas vias com medidas repetidas e testes post-hoc nos grupos com DMS. Resultados: O peso corporal ( $p<0,01$ e $p<0,001)$ e percentual de gordura corporal $(p<0,05$ e $p<0,01)$ diminuíram significativamente em todos os grupos e a visfatina só aumentou significativamente depois do exercício no grupo EARV $(p<0,05)$. Triglicérides, glicose e circunferência da cintura $(p<0,05, p<0,01$ e $p<0,001)$ diminuíram significativamente em todos os grupos e o HDL-C $(p<0,05)$ só aumentou significativamente depois o exercício apenas no grupo EARM. Conclusão: Esses resultados sugerem que, apesar das diferenças de intensidade e tipo dos exercícios, eles são eficazes para melhorar a obesidade e os fatores de risco da SM, porém, são necessárias mais pesquisas sobre os mecanismos exatos da visfatina. Nível de Evidência l; Estudos terapêuticos - Investigação dos resultados do tratamento.

Descritores: Visfatina; Síndrome metabólica.

\section{RESUMEN}

Objetivo: La visfatina puede regular diversas funciones fisiológicas y tiene gran potencial para mejorar significativamente nuestro conocimiento sobre el tratamiento del sindrome metabólico. El síndrome metabólico (SM) se refiere a anormalidades metabólicas, como obesidad abdominal, dislipidemia, colesterol de baja densidad elevado, hipertensión y diabetes, siendo la actividad física un factor importante para el manejo del SM. Siendo así, el objetivo 
de este estudio es investigar los efectos de la visfatina sobre los factores de riesgo de SM por medio de diferencias de la intensidad de ejercicios aeróbicos y del tipo de ejercicio, con base en la premisa de misma cantidad de ejercicio (gasto energético de $400 \mathrm{kcal}$ por día). Método: Treinta y dos mujeres obesas de media edad fueron aleatoriamente designadas para grupos de intensidad de ejercicio con $\mathrm{VO}_{2 \text { máx }}$ de $50 \%(E A M, n=8)$ y $\mathrm{VO}_{2 \text { máx }}$ de $80 \%(E A V, n=8)$ y grupos con VO ${ }_{2 \text { máx }}$ de $50 \%+E R C(E A R M, n=8)$ y VO ${ }_{2 \text { máx }}$ de $80 \%+E R C(E A R V, n=8)$. El programa de ejercicios fue realizado cinco veces por semana. Los datos fueron analizados con ANOVA de dos vías con medidas repetidas y tests post-hoc en los grupos con DMS. Resultados: El peso corporal ( $p<0,01$ y $p<0,001$ ) y porcentual de grasa corporal ( $p<0,05$ y $p$ $<0,01)$ disminuyeron significativamente en todos los grupos y la visfatina sólo aumentó significativamente después del ejercicio en el grupo EARV $(p<0,05)$. Los triglicéridos, la glucosa y la circunferencia de la cintura $(p<0,05, p<0,01$ e $p<0,001)$ disminuyeron significativamente en todos los grupos y el HDL-C $(p<0,05)$ sólo aumentó significativamente después del ejercicio sólo en el grupo EARM. Conclusión: Esos resultados sugieren que, a pesar de las diferencias de intensidad y tipo de los ejercicios, los mismos son eficaces para mejorar la obesidad y los factores de riesgo del SM, por ende, son necesarias más investigaciones sobre los mecanismos exactos de la visfatina. Nivel de Evidencia I; Estudios terapéuticos - Investigación de los resultados del tratamiento.

\section{Descriptores: Visfatina; Síndrome metabólico.}

\section{INTRODUCTION}

Obesity is the excessive or abnormal accumulation of fat or adipose tissue in the body that impairs health via its association to the risk of development of diabetes mellitus, cardiovascular disease, hypertension, and hyperlipidemia. The current view of adipose tissue is that of an active secretory organ, sending out and responding to signals that insulin sensitive and energy expenditure. ${ }^{1}$

Visfatin, which is alternatively known as pre-B-cell colony-enhancing factor (PBEF), is a highly expressly protein in visceral adipose tissue. ${ }^{2,3} \mathrm{It}$ may act as an autocrine, paracrine and endocrine mediator and participate in the regulation of a variety of physiological functions including cell proliferation, synthesis of nicotinamide mono- and dinucleotide and glucose homeostasis. ${ }^{4}$ This curious adipokine has great potential to significantly enhance our knowledge of the metabolic syndrome treatment. In previous studies, exercise stimulates the secretion of visfatin, but the results of the study were inconsistent and may be due to differences in the subject's physical characteristics and exercise methods. ${ }^{5-8}$

Metabolic syndrome(MS) refers to metabolic abnormalities such as abdominal obesity, dyslipidemia, High low-density cholesterol, high blood pressure and diabetes, ${ }^{9}$ and the causes are low physical activity, unhealthy diets and genetic factors. ${ }^{10}$ This syndrome has a higher prevalence rate in people with low physical activity and obesity and it is that weight control and increased physical activity are important factors for management of MS. ${ }^{11,12}$ Most of previous studies on risk factors for MS only used aerobic exercise, ${ }^{13,14}$ and some studies have suggested that combined aerobic is better than aerobic exercise alone for improving MS components. ${ }^{8,15}$

However, nonscientific and ineffective exercise program rather decrease in exercise capacity. ${ }^{16}$ Thus, intensity, volume, frequency, and type of exercise must be considered important for maximize the effect of exercise program. ${ }^{17}$

The purpose of this study is to investigate on effect of visfatin and risk factors of MS by difference in aerobic exercise intensity(VO2max $50 \%$ vs. VO2max 80\%) and exercise type(VO2max 50\% + resistance exercise vs. $\mathrm{VO} 2 \mathrm{max} 80 \%$ + resistance exercise), based on the premise of the same amount of exercise(energy expenditure of $400 \mathrm{kcal}$ per day). ${ }^{18}$

\section{MATERIALS AND METHODS}

\section{Subjects}

This study included 32 obese (over 30\% body fat) middle-age women without any previous diagnosis of metabolic disease and no other health problems. The subjects were informed of the procedures and signed an informed consent document before participation. They instructed to maintain their typical diet pattern throughout the study and compliance with this instruction was assessed vis food questionnaires. The subjects were randomly assigned to groups VO2max 50\%(moderate aerobic exercise, MAE, $\mathrm{n}=8$ ) and $\mathrm{VO} 2 \mathrm{max} 80 \%$ (vigorous aerobic exercise, $\mathrm{VAE}$, $n=8$ ) according to intensity of exercise and to groups VO2max $50 \%+$ TRX(Totally Body Resistance Exercise)(moderate aerobic and resistance exercise, MARE, $n=8$ ) and VO2max 80\% + TRX(vigorous aerobic and resistance exercise, VARE, $\mathrm{n}=8$ ) according to mode of exercise. The physical characteristics of subjects are shown in Table 1.

\section{Blood samples and analysis}

Blood samples were obtained from antecubital vein after a 12-hour fast at pre and post 8 weeks exercise and collected into vacutainer tubes with EDTA under same condition and time periods. The collected blood was centrifuged at $3000 \mathrm{rpm}$ for 30 minutes and storage in a deep freezer at $-70^{\circ} \mathrm{C}$. The method of blood analysis is shown in Table 2.

\section{Waist circumstance measurement}

The waist circumference was measured between lower rib and upper iliac crest at the standing position by one certified expert and all processes were conducted according to the contents of International society for advanced kinanthropometry(ISAK).

Table 1. The characteristics of subjects.

\begin{tabular}{c|c|c|c|c}
\hline Group $(\mathrm{N}=32)$ & Age (years) & Height $(\mathbf{c m})$ & Weight $(\mathbf{k g})$ & Body fat $(\%)$ \\
\hline MAE $(n=8)$ & $48.63 \pm 1.69$ & $160.90 \pm 2.73$ & $64.58 \pm 4.84$ & $35.23 \pm 1.04$ \\
\hline $\operatorname{VAE}(n=8)$ & $45.38 \pm 2.75$ & $160.89 \pm 0.77$ & $64.95 \pm 3.84$ & $34.43 \pm 1.53$ \\
\hline MARE $(n=8)$ & $42.25 \pm 2.17$ & $159.65 \pm 1.88$ & $65.00 \pm 3.58$ & $34.98 \pm 1.20$ \\
\hline VARE $(n=8)$ & $43.00 \pm 2.41$ & $163.18 \pm 1.46$ & $68.63 \pm 3.83$ & $35.23 \pm 1.50$ \\
\hline
\end{tabular}

Values are Means \pm SED. MAE, moderate aerobic exercise group; VAE, vigorous aerobic exercise group; MARE, moderate aerobic and resistance exercise; VARE, vigorous aerobic and resistance exercise.

Table 2. Analysis of blood.

\begin{tabular}{c|c|c|c}
\hline Visfatin & Analyzer & Reagent & Method \\
\hline HDL-C & $\begin{array}{c}\text { Modular Analytics } \\
\text { PE (Germany) }\end{array}$ & $\begin{array}{c}\text { Human Visfatin } \\
\text { ELISA (Korea) } \\
\text { generation (Germany) }\end{array}$ & $\begin{array}{c}\text { Enzymatic } \\
\text { Colorimetric Assay }\end{array}$ \\
\hline Glucose & $\begin{array}{c}\text { Modular analytics } \\
\text { PE (Germany) }\end{array}$ & GLU (Germany) & Enzymatic Kinetic Assay \\
\hline TG & $\begin{array}{c}\text { Modular analytics } \\
\text { PE (Germany) }\end{array}$ & TG (Germany) & $\begin{array}{c}\text { Enzymatic } \\
\text { Colorimetric Assay }\end{array}$ \\
\hline
\end{tabular}

HDL-c, High density lipoprotein cholesterol; TG, Triglyceride. 


\section{Exercise intensity measurement}

To measure the exercise intensity, 1 mile(1609m) walk was performed using a heart rate meter (Polar, Finland), and the rating of perceived exertion(RPE) was checked every minute to adjust the exercise duration and speed during the test. After test, the maximum oxygen intake per body weight(VO2max) was estimated using exercise time and heart rate by follow formula. ${ }^{19}$

$\mathrm{VO}_{2} \mathrm{max}(\mathrm{ml} / \mathrm{min} / \mathrm{kg})=132.853-(0.1692 \times$ body mass in $\mathrm{kg})$

- (0.3877xage) + (6.315xgender) - (3.2649xtime in min) -

$(0.1565 \times \mathrm{HR})$

<gender, men $=1$, women $=0 ; H R$, heart rate immediately walking $>$

\section{Exercise program}

The exercise program in this study is shown in Table 3 and each group performed 5 times a week. Energy consumption used Polar to measure $400 \mathrm{kcal}$ from the time target intensity was reached. Exercise intensity and RPE continuously supervised and then exercise speed adjusted until the end of exercise.

\section{Statistical Analysis}

All data analyses in this study were conducted using the IBM SPSS Statistics ver. 22.0(IBM, New York, USA). Means and standard errors for all measurement were calculated. Repeated-measurement two-way ANOVA was used to determine differences between groups and time for measured variables. Post-hoc analysis was used to determine difference within groups with $L S D$ and the level of significance was set at $\alpha=05$.

\section{RESULTS}

\section{Body composition}

After 8 weeks of exercise, there was no significant interaction effect between group and time in body weight and \%body fat. In results of main effect test, body weight $(p<.01, \& p<.001)$ and \%body fat $(p<.05$, $\& p<.01$ ) significantly decreased after exercise in all groups. (Table 4 )

Table 3. Exercise program.

\begin{tabular}{|c|c|c|c|}
\hline \multicolumn{2}{|c|}{ Exercise type } & Exercise program & $\begin{array}{l}\text { Expenditure } \\
\text { calorie }\end{array}$ \\
\hline \multicolumn{2}{|c|}{ Warming up } & Stretching (15min) & \\
\hline \multirow{4}{*}{$\begin{array}{l}\text { Main } \\
\text { Exercise }\end{array}$} & $\operatorname{MAE}(\mathrm{n}=8)$ & Treadmill - $\mathrm{VO}_{2 \max } 50 \%$ & Aerobic: $400 \mathrm{kcal}$ \\
\hline & $\operatorname{VAE}(n=8)$ & Treadmill - $\mathrm{VO}_{2 \max } 80 \%$ & Aerobic: $400 \mathrm{kcal}$ \\
\hline & MARE $(n=8)$ & $\begin{array}{c}\text { Treadmill - } \mathrm{VO}_{2 \max } 50 \%+\mathrm{TRX} \text { : } \\
\text { TRX program - push up, standing row, } \\
\text { kneeling triceps extension, } \\
\text { biceps curl, jump squat, } \\
\text { lunge, leg curl, ab slide, } \\
\text { revers lying knee pull }\end{array}$ & $\begin{array}{l}\text { Aerobic: } 200 \mathrm{kcal} \\
\text { Resistance: } 200 \mathrm{kca}\end{array}$ \\
\hline & $\operatorname{VARE}(\mathrm{n}=8)$ & $\begin{array}{c}\text { Treadmill - } \mathrm{VO}_{2 \max } 80 \%+\mathrm{TRX} \text { : } \\
\text { TRX program - push up, standing row, } \\
\text { kneeling triceps extension, } \\
\text { biceps curl, jump squat, } \\
\text { lunge, leg curl, ab slide, } \\
\text { revers lying knee pull } \\
\end{array}$ & $\begin{array}{l}\text { Aerobic: } 200 \mathrm{kcal} \\
\text { Resistance: } 200 \mathrm{kca}\end{array}$ \\
\hline \multicolumn{2}{|c|}{ Cool down } & Stretching (15min) & \\
\hline
\end{tabular}

Table 4. The change of body weight $(\mathrm{kg})$ and body fat.

\begin{tabular}{|c|c|c|c|c|}
\hline \multirow{2}{*}{$\begin{array}{c}\text { Time } \\
\text { Group }(\mathrm{N}=32)\end{array}$} & \multicolumn{2}{|c|}{ Body weight } & \multicolumn{2}{|c|}{ Body fat } \\
\hline & Pre-exercise & Post-exercise & Pre-exercise & Post-exercise \\
\hline $\operatorname{MAE}(n=8)$ & $65.00 \pm 10.12$ & $59.64 \pm 8.52^{* *}$ & $35.23 \pm 2.94$ & $30.29 \pm 4.70^{*}$ \\
\hline $\operatorname{VAE}(n=8)$ & $68.63 \pm 10.82$ & $63.09 \pm 8.88^{* * *}$ & $34.43 \pm 4.34$ & $29.05 \pm 4.81^{* *}$ \\
\hline MARE $(n=8)$ & $64.58 \pm 13.69$ & $61.53 \pm 14.18^{* *}$ & $34.98 \pm 3.39$ & $28.73 \pm 4.75^{* *}$ \\
\hline VARE $(n=8)$ & $66.95 \pm 10.87$ & $63.64 \pm 9.51 * *$ & $35.23 \pm 4.25$ & $28.15 \pm 4.86^{* *}$ \\
\hline
\end{tabular}

\section{Visfatin}

After 8 weeks of exercise, there was no significant interaction effect between group and time in change of visfatin. In results of main effect test, only $\operatorname{VARE}(p<.05)$ significantly increased after exercise and other groups did not reach to statistics level, although these showed trend of increasing. (Table 5)

\section{Risk factors of metabolic syndrome}

After 8 weeks of exercise, there was no significant interaction effect between group and time in TG, glucose, $\mathrm{HDL}-\mathrm{C}$, and waist circumstance. In results of main effect test, $\mathrm{TG}$, glucose, and waist circumstance $(p<.05$, $p<.01, \& p<.001)$ significantly decreased after exercise in all groups and $\mathrm{HDL}-\mathrm{C}(p<.05)$ significantly increased after exercise in only MAR, although other groups trend of increasing. (Table 6)

Table 5. The change of visfatin.

\begin{tabular}{c|c|c}
\hline $\begin{array}{c}\text { Time } \\
\text { Group }(\mathbf{N}=\mathbf{3 2})\end{array}$ & Pre-exercise & Post-exercise \\
\hline $\operatorname{MAE}(n=8)$ & $0.98 \pm 0.18$ & $1.01 \pm 0.15$ \\
\hline $\operatorname{VAE}(n=8)$ & $1.47 \pm 0.30$ & $1.82 \pm 0.33$ \\
\hline $\operatorname{MARE}(n=8)$ & $1.08 \pm 0.27$ & $1.10 \pm 0.33$ \\
\hline $\operatorname{VARE}(n=8)$ & $1.05 \pm 0.17$ & $1.58 \pm 0.25^{*}$ \\
\hline
\end{tabular}

Values are Means \pm SEM. ${ }^{*} p<.05$, significantly different between pre- vs. post-exercise.

Table 6. Change of risk factors for metabolic syndrome.

\begin{tabular}{|c|c|c|c|c|c|}
\hline \multicolumn{2}{|c|}{$\begin{array}{c}\text { Group }(\mathrm{N}=32) \\
\text { Time }\end{array}$} & TG & Glucose & HDL & $\begin{array}{c}\text { Waist } \\
\text { circumstance }\end{array}$ \\
\hline \multirow{2}{*}{$\operatorname{MAE}(\mathrm{n}=8)$} & pre & $92.17 \pm 21.43$ & $92.86 \pm 6.80$ & $60.17 \pm 4.17$ & $88.14 \pm 10.60$ \\
\hline & post & $59.13 \pm 19.13^{* * *}$ & $81.71 \pm 6.84^{* * *}$ & $69.17 \pm 11.32^{*}$ & $79.45 \pm 10.33^{*}$ \\
\hline \multirow{2}{*}{$\operatorname{VAE}(\mathrm{n}=8)$} & pre & $82.63 \pm 21.59$ & $96.57 \pm 9.15$ & $64.25 \pm 13.12$ & $89.19 \pm 10.64$ \\
\hline & post & $57.13 \pm 14.28^{* *}$ & $86.29 \pm 8.75^{* *}$ & $65.38 \pm 10.10$ & $82.75 \pm 10.50^{*}$ \\
\hline \multirow{2}{*}{$\operatorname{MARE}(\mathrm{n}=8)$} & pre & $88.92 \pm 22.85$ & $90.38 \pm 4.69$ & $68.63 \pm 18.30$ & $88.49 \pm 8.07$ \\
\hline & post & $65.50 \pm 21.85^{*}$ & $83.71 \pm 6.96^{*}$ & $71.00 \pm 16.22$ & $78.43 \pm 7.09^{*}$ \\
\hline \multirow{2}{*}{$\operatorname{VARE}(n=8)$} & pre & $77.13 \pm 31.70$ & $91.75 \pm 10.90$ & $57.48 \pm 13.81$ & $89.09 \pm 11.69$ \\
\hline & post & $57.40 \pm 11.13^{*}$ & $85.711 \pm 7.53^{*}$ & $62.85 \pm 14.51$ & $79.39 \pm 12.08^{*}$ \\
\hline \multicolumn{2}{|c|}{$p$-value $(G \times T)$} & $<.001$ & $<.001$ & $<.05$ & $<.001$ \\
\hline
\end{tabular}

\section{DISCUSSION}

The study analyzed the effect of exercise intensity and exercise type on the level of visfatin concentration and metabolic syndrome(MS) risk factor in middle-aged obese women.

\section{Body weight and \% body fat}

Low physical activity can lead to obesity by increasing fat content in the body and many previous studies have reported that it is linked to obesity. 20,21

In most previous studies, it was found that aerobic exercise, 22,23 resistance exercise, ${ }^{24,25}$ and combined exercise ${ }^{8}$ decreased body weight and \% body fat. In this study, both body weight and body fat percentage were decreased in all exercise groups, which was consistent with the results of previous studies. These results suggested that fat metabolism promote regardless of the intensity or type of exercise if there is minimal exercise stimulation for fat oxidation and caloric expenditure and therefor exercise is one the best treatment for decreasing weight and body fat.

\section{Visfatin}

In the treatment of obesity, reduction of body fat mass, which is visceral and subcutaneous fat, is the most important goal. Initially, visfatin was described as a protein preferentially produced in visceral fat. ${ }^{2}$ However, other study find no difference with regard to expression of visfatin by visceral and subcutaneous fat. ${ }^{26}$ 
In a few previous studies, visfatin level increased with obesity in human ${ }^{26,27}$ but reduced rather in other study, ${ }^{28}$ this contradictory data have an unclear explanation. And the relationship between the reduction of fat mass and the secretion of visfatin also remains unclear. In the studies of relationship between exercise and visfatin secretion, Choi et al. (2007) and Seo et al. (2011) reported decrease in visfatin after exercise, but Ghanbari-Niaki et al. (2010) showed increase, therefore the results of previous studies were inconsistent.

The result of this study was also significantly increased after exercise in a group of combined with high intensity aerobic exercise and resistance exercise(VARE) and consistent with the result of Ghanbari-Niaki et al. (2010). These results suggest that visfatin is increased by an increase in insulin concentration immediately after high-intensity exercise, but its precise mechanism is not still clear. On the other hand, the difference in visfatin response by exercise may be appear in various ways depending on the sample size, physical characteristics of subject, and exercise method.

\section{Metabolic syndrome risk factors}

Metabolic syndrome(MS) have been known to increase the incidence of hypertension, hyperlipidemia, cardiovascular disease and diabetes. ${ }^{9}$ The risk factors for MS include higher triglyceride levels $(\geq 150 \mathrm{mg} / \mathrm{dl}$, $\mathrm{TG})$, higher fasting glucose levels( $\geq 100 \mathrm{mg} / \mathrm{dl}$ ), lower high density lipoprotein cholesterol levels $(<50 \mathrm{mg} / \mathrm{dl}$ for women and $<40 \mathrm{mg} / \mathrm{dl}$ for men, HDL-C), higher blood pressure $(\geq 130 / 80 \mathrm{mmHg})$, and a large waist circumstance $\left(\geq 88 \mathrm{~cm}\right.$ for women and $\geq 102 \mathrm{~cm}$ for men, WC). ${ }^{29,30}$ Regular exercise is known to reduce body fat as well as the onset rate of metabolic diseases and cardiovascular diseases, ${ }^{31}$ but there is no consistent results of studies on various exercise intensity or type.

High TG level and low HDL-C level, which promotes and the onset of hypertension by increasing the level of free fatty acids in adipose tissues, are major risk factor for metabolic syndrome. ${ }^{1}$ In previous studies, risk factors for MS have been improved by exercise. ${ }^{8-15}$ Obesity or overweight, which promotes insulin resistance or type 2 diabetes mellitus by high level of glucose in the blood, could increase utilization rate of glucose in the muscle by exercise and therefore exercise may be prevents to metabolic syndrome. ${ }^{32}$ WC is associated with body weight and had a decreased after exercise in obese middle-aged women. ${ }^{8}$

In this study, changes in fasting glucose, HDL-C, TG, and waist circumference, which are risk factors for metabolic syndrome, were measured pre- and post-exercise for 8 weeks by factorial design. These factors, that included fasting glucose, TG, and waist circumstance, showed significant improvement following the exercise intervention, although $\mathrm{HDL}-\mathrm{C}$ only significantly changed in MAE. These results suggested that the effect of improving MS risk factors was the greatest in low-intensity aerobic exercise, and followed by combined exercise.

\section{CONCLUSION}

We found that 8 weeks exercise programs, which were difference in exercise intensity and type(VO2max 50\% vs. VO2max 80\% vs, VO2max $50 \%$ +resistance exercise vs. VO2max 80\%+ resistance exercise), increased visfatin level and are effective in modifying risk factors for MS in obese middle-aged women. Theses results suggested that, in spite of differences in exercise intensity and exercise mode, exercise is effective in improving obesity and MS risk factors, but further research need on the exactly mechanisms of visfatin.

\section{ACKNOWLEDGEMENT}

The present research was supported by the research fund of Dankook University in 2021.

All authors declare no potential conflict of interest related to this article

AUTHORS' CONTRIBUTIONS: JKL was responsible for the entire research project, including study design, data analysis, and the writing, intellectual content and critical review of the manuscript.

\section{REFERENCE}

1. Wajchenberg BL. Subcutaneous and visceral adipose tissue: their relation to the metabolic syndrome. Endocr Rev. 2000;21(6):697-738.

2. Fukuhara A, Matsuda M, Nishizawa M, Segawa K, Tanaka M, Kishimoto K, et al.Visfatin: a protein secreted by visceral fat that mimics the effects of insulin. Science. 2005;307(5708):4264-30.

3. Revollo JR, Körner A, Mills KF, Satoh A, Wang T, Garten A, et al. Nampt/PBEF/Nisfatin regulates insulin secretion in beta cells as a systemic NAD biosynthetic enzyme. Cell Metab. 2007;6(5):363-75.

4. Adeghate E. Visfatin: structure, function and relation to diabetes mellitus and other dysfunctions. Curr Med Chem. 2008;15(18):1851-62

5. Choi KM, Kim JH, Cho GJ, Baik SH, Park HS, Kim SM. Effect of exercise training on plasma visfatin and eotaxin levels. Eur J Endocrinol. 2007;157(4):437-42

6. Ghanbari-Niaki A, Saghebjoo M, Soltani R, Kirwan JP. Plasma visfatin is increased after high-intensity exercise. Ann Nutr Metab. 2010;57(1):3-8.

7. Haider DG, Pleiner J, Francesconi M, Wiesinger GF, Müller M, Wolzt M. Exercise training lowers plasma visfatin concentrations in patients with type 1 diabetes. J Clin Endocrinol Metab. 2006;91(11):4702-4704.

8. Seo DI, So WY, Ha S, Yoo EJ, Kim D, Singh H, et al. Effects of 12 weeks of combined exercise training on visfatin and metabolic syndrome factors in obese middle-aged women. J Sports Sci Med. 2011;10(1):222-6.

9. Isomaa B. A major health hazard: the metabolic syndrome. Life Sci. 2003;73(19):2395-411.

10. Eckel RH, Grundy SM, Zimmet PZ. The metabolic syndrome. Lancet. 2005;365(9468):1415-28.

11. Duncan GE. Exercise, fitness and cardiovascular disease risk in type 2 diabetes and metabolic syndrome. Current diabetes Reports. 2006;6(1):29-35.

12. Sarti C, Gallagher J. The metabolic syndrome: prevalence, CHD risk, and treatment. J Diabetes Complications. 2006;20(2):121-32.

13. Katzmarzyk PT, Perusse L, Malina RM, Bergeron J, Despres FP, Bouchard C. Stability of indicators of the metabolic syndrome from childhood and adolescence to young adulthood: the Quebec Family Study. J Clin Epidemiol. 2001;54(2):190-5.

14. Kelley GA, Kelley KS, Tran ZV. Exercise, lipids, and lipoproteins in older adults: a meta-analysis. Prev Cardiol. 2005;8(4):206-14.

15. Strasser B, Schobersberger W. Evidence for resistance training as a treatment therapy in obesity. J Obes. 2011;10:1-9.

16. Hawley JA. Adaptations of skeletal muscle to prolonged, intense endurance training. Clin Exp Pharmacol Physiol. 2002;29(3):218-22.

17. Hawley JA. Specificity of training adaptation: time for a rethink? J Physiol. 2008;586(1):1-2.
18. Donnelly JE, Blair SN, Jakicic JM, Manore MM, Rankin JW, Smith BK. American College of Sports Medicine Position Stand. Appropriate physical activity intervention strategies for weight loss and prevention of weight regain for adults. Med Sci Sports Exerc. 2009;41(2):459-71.

19. Rintala P, Dunn JM, McCubbin JA, Quinn C. Validity of a cardiorespiratory fitness test for men with mental retardation. Med Sci Sports Exerc. 1991;24(8):941-5

20. Fleg JL, Morrell CH, Bos AG, Brant $L$, Talbot LA, Wright JG, et al. Accelerated longitudinal decline of aerobic capacity in healthy older adults. Circulation. 2005;112(5):674-82

21. Lovejoy JC, Champagne CM, de Jonge L, Xie H, Smith SR. Increased visceral fat and decreased energy expenditure during the menopausal transition. Int J Obes (Lond). 2008;32(6):949-58.

22. Cao L, Jiang Y, Li Q, Wang J, Tan S. Exercise Training at Maximal Fat Oxidation Intensity for Overweight or Obese Older Women: A Randomized Study. J Sports Sci Med. 2009;18(3):413-8.

23. Tan S, Wang J, Cao L, Guo Z, Wang Y. Positive effect of exercise training at maximal fat oxidation intensity on body composition and lipid metabolism in overweight middle-aged women. Clin Physiol Funct Imaging. 2016;36(3):225-30.

24. Brochu M, Malita MF, Messier V, Doucet E, Strychar I, Lavoie JM. Prud'homme, D., Rabasa-Lhoret R., Resistance training does not contribute to improving the metabolic profile after a 6-month weight loss program in overweight and obese postmenopausal women. J Clin Endocrinol Metab. 2009;94(9):3226-33.

25. Park KM, Park SC, Kang S. Effects of resistance exercise on adipokine factors and body composition in pre- and postmenopausal women. J Exerc Rehabil. 2009;15(5):676-82.

26. Berndt J, Klöting N, Kralisch S, Kovacs P, Fasshauer M, Schön MR, et al. Plasma visfatin concentrations and fat depot-specific mRNA expression in humans. Diabetes. 2005;54(10):2911-016.

27. Chen CC, LiTC, Li Cl, Liu CS, Lin WY, Wu MT, et al. The relationship between visfatin levels and anthropometric and metabolic parameters: association with cholesterol levels in women. Metabolism. 2007;56(9):1216-20.

28. Pagano C, Pilon C, Olivieri M, Mason P, Fabris R, Serra R, et al. Reduced plasma visfatin/pre-B cell colony-enhancing factor in obesity is not related to insulin resistance in humans. J Clin Endocrinol Metab. 2006;91(8):3165-70

29. Gale EA. Should we dump the metabolic syndrome? Yes. BMJ. 2008;336(7645): 640.

30. Gupta A, Gupta V. Metabolic syndrome: what are the risks for humans? Biosci Trends. 2010;4(5):204-12.

31. Shulman Gl. Cellular mechanisms of insulin resistance. J Clin Invest. 2000;106(2):171-6.

32. Shahid SK, Schneider SH. Effects of exercise on insulin resistance syndrome. Coron Artery Dis. 2000;11(2):103-9. 